\title{
GEOSPATIAL MODEL FOR LARGE SCALE SEA CLIFF ROCKFALL SUSCEPTIBILITY MAPPING
}

\author{
P. Redweik ${ }^{1}$, R.Matildes ${ }^{2}$, F. Marques ${ }^{3}$ \\ ${ }^{1}$ Department of Geographic Engineering, Geophysics and Energy, Instituto Dom Luiz, Faculty of Sciences, University of Lisbon, \\ Campo Grande, 1749-016 Lisbon, Portugal - predweik@fc.ul.pt \\ ${ }^{2}$ Centre of History, School of Arts and Humanities, University of Lisbon, Alameda da Universidade, 1600-214 Lisbon, Portugal - \\ rmatildes@letras.ulisboa.pt \\ ${ }^{3}$ Department of Geology, Instituto Dom Luiz, Faculty of Sciences, University of Lisbon, Campo Grande, 1749-016 Lisbon, Portugal \\ - fsmarques@fc.ul.pt
}

KEY WORDS: photogrammetry, cliff erosion, logistic regression, predisposing factors

\begin{abstract}
:
Due to their relevance to the environment and economy, coastal areas are considered national strategic segments that should be preserved. Since erosion phenomena occur intensively in those areas, it is capital to monitor them in order to identify risk zones. In addition to national and regional studies, it is also necessary to conduct local monitoring of erosion prone areas, especially those which are often frequented by people, such as beaches limited by high cliffs. Large scale vertical mapping is necessary to model their susceptibility to mass movements, in order to provide adequate prevention, protection and assistance.

Recent techniques like laser scanning or aerial photogrammetry using UAVs allow the definition of the status quo of a cliff wall and its situation a few years back. But to assess the susceptibility to rock mass movements in such cliff segments, inventories of past events are of primordial importance. These inventories allow applying several statistic models to better understand susceptibility together with a set of variables of internal and external nature regarding the cliff site.

We present a case study focused on the beach of Ribeira d'Ilhas (Mafra, Portugal), where a workflow of terrestrial photogrammetry for present day situation and recovery of old analogue stereoscopic pairs (1999, 2000, 2003) was implemented. A mass movement inventory (1999-2014) was compiled by multitemporal comparison followed by a detailed characterization of the cliff using a GIS software. Finally, the application of the logistic regression method allowed the definition of a susceptibility map of the cliff wall towards the occurrence of mass movements.
\end{abstract}

\section{INTRODUCTION}

\subsection{Motivation}

Coastal areas are vital for the environment as well as for the economy of littoral countries. As an interface between land and sea, in addition to shelter beaches and areas suitable for tourism, the coast also hosts other economically relevant industry infrastructures related to the sea. Sand beaches are affected by accretion and erosion, mostly in a cyclic behaviour with a short period (one or several years). Sea rocky cliffs, on the other hand, suffer often sudden erosion on the top and face, mostly by rockfall, and debris deposition on the base. When directly impacted by waves, the base can also be eroded causing severe instability of the cliff. Since cliff erosion affects areas near the top as well as areas near the base, it is very important to monitor their behaviour in order to define set back lines or take other measures to safeguard lives and property. Cliff monitoring is normally based on periodic surveys and comparison of the acquired data in the different observation epochs. Contrasting with the intensity of each erosion event, which consists of a sudden mass movement down the cliff, the frequency of such events is low, following an inverse power law (Marques, 2008). Due to this fact, a wide temporal window for the observations is needed in order to be able to classify the cliffs according to their susceptibility to rockfall. Cliff top evolution has been studied for several years based on series of aerial photographs of different epochs (Horikawa and Sunamura, 1967; Sunamura and Horikawa, 1969; Lim et al., 2005; Zviely et al., 2004; Hapke, 2004). In Portugal those studies include aerial surveys from 1943 (in some regions even from 1938) to 2010 (Marques,
1997, 2006, 2018; Catalão et al., 2002; Oliveira et al., 2008; Redweik et al., 2008, 2009, 2016; Matildes et al., 2009; Marques et al., 2011, 2013; Queiroz and Marques, 2019).

Aerotriangulation for georreferencing the images of each flight and stereo plotting of cliff top and cliff base (where visible) in each epoch were the methods used to acquire the data at regional and national scale. Since vertical aerial photographs are, in general, not suitable to acquire data on the cliff walls, where most mass movement events occur, other methods are applied such as terrestrial photogrammetry (TP), terrestrial laser scanning (TLS) (Rosser et al., 2005; Lim et al., 2005; Collins and Stock, 2012; Hoffmeister et al., 2012; Katz and Mushkin, 2012; Salvini et al., 2013) and aerial photogrammetry using UAVs (Letortu et al., 2018). Usually, the extension of the study areas is local due to the huge amount of data to process. TLS and TP require access to the cliff base and a certain distance from the cliff wall for suitably acquiring the data. These techniques are normally applied in beaches that are surrounded by high cliffs. The model presented in this study was applied to a beach, recurring to older photographs, in analogue format, and more recent photogrammetric surveys, in order to enlarge the temporal window of the observations. The differences found on the cliff wall were analysed and an inventory of movements was built. Each movement was classified according to several parameters considered relevant for the rockfall process. At last a statistical prediction model was adapted to the variables. A susceptibility map of the cliff wall was generated as a result. The innovation of this work lies in several aspects: the study focuses on the cliff wall in 3D instead of analysing cliff top lines in 2D; the terrain units used are 3D points and not an interpolated surface area; predisposing factors of geometric 
nature are calculated directly in the point cloud, for each terrain unit; a new method for deriving material resistance of the cliff layers is presented; the monitoring period of 15 years for this kind of object is unique in the literature; the level of detail of the results is maintained throughout the process.

\subsection{Study Area}

The beach of Ribeira d'Ilhas, belongs to the World Surfing Reserve of Ericeira, Portugal. As a consequence, it is crowded on several occasions throughout the year. It is located on the west coast of Portugal, about $35 \mathrm{~km}$ north of Lisbon, and the studied cliff sector extends for $300 \mathrm{~m}$ on the north side of the beach (Fig.1).
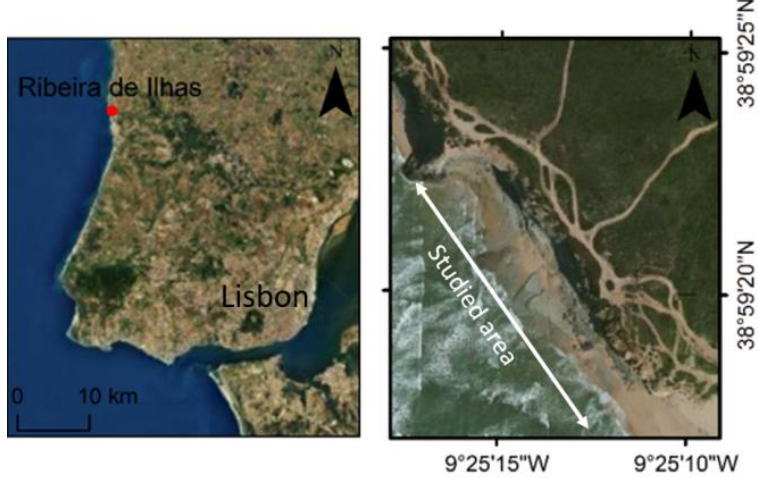

Figure 1. Ribeira d'Ilhas and study area (adapted from Matildes, 2016)

During low tide, a very extensive and almost horizontal rock platform becomes exposed making it possible to photograph the wall from a fair distance. The geologic structure of the cliff is composed by a sequence of near horizontal alternating layers of marly limestones, marls and sandstone beds cut by minor faults and three dykes (Marques, 2008). At the northern end of the sector there is a basaltic neck. The sector is exposed to the high energy north Atlantic wave regime where several storms and high waves occur.

The irregular vertical profile of this cliff is due to the differential erosion caused by different resistance materials which form protruding layers with little support from the softer layers below. The accumulation of mass movement debris in the base of the cliff takes place along the cliff segment and offers some protection from waves to the cliff toe in high tide periods.

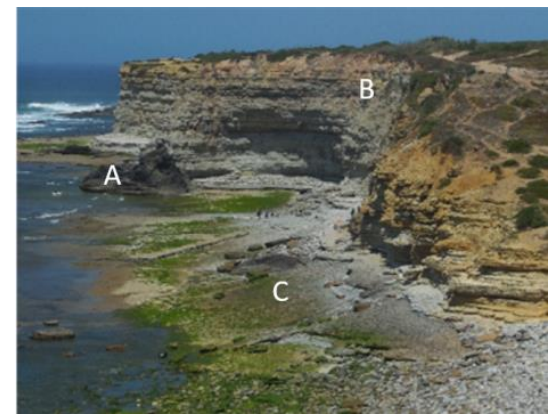

Figure 2. View of the studied sector showing the basaltic neck (A), the vertical profile (B) and the abrasion platform (C)

\section{METHODOLOGY}

\subsection{Analogue and digital photogrammetric surveys}

Marques (2008) presents a local scale work on movements in the face of the Ribeira d'Ilhas cliff segment, based on terrestrial photography.

Although very rich from the geometric and geological points of view, the mass movement inventory, composed of 103 rockfall events, was based on systematic and stereoscopic terrestrial photographic survey, simplified measuring methods and stereoscopic observation. These surveys of 1999, 2000 and 2003 were composed by independent stereo pairs that did not have a common overlapping area. Thus, they could not be considered photogrammetric surveys.

Retreat rates for a 4-year period (1999-2003) were determined as well as estimates of the mean thickness of the displaced blocks and volumes, with the support of an additional convergent photograph (Marques, 2008)

A digital photogrammetric survey of the same cliff face, carried out in 2014, allowed establishing a monitoring period of about 15 years (1999-2014), unique in the literature.

The geometric recovery of the analogue photos of the 1999 , 2000 and 2003 surveys was achieved by measuring 41 common control points with a total station on the field, which were determined by detailed and systematic observation of all available images. The DLT (Direct Linear Transformation) method was applied to estimate the interior and exterior orientations as no information about the camera or image capture conditions was available.

The photogrammetric process was carried out using PhotoModeler Scanner (EOS Systems Inc., 2013) yielding four 3D point clouds, one for each survey epoch, which were then analysed. Due to alignment issues and poor geometric accuracy in the 1999 and 2000 point clouds, only the 3D point clouds of 2003 and 2014 were compared for mass movement inventory purposes, using CloudCompare software (GPL software, 2015) and the M3C2 algorithm (Lague et al., 2013).

\subsection{Data pre-processing}

Susceptibility, or the probability of a mass movement occurring in a cliff segment, can be determined using statistical methods that correlate local terrain conditions (predisposing factors) with an inventory of mass movement events occurred in the same area(e.g. Guzzetti, 2005). For the application of these type of methods the study area must be divided in smaller portions of terrain which have nearly constant properties, usually named as terrain units.

The logistic regression method allows the analysis of the contribution of each factor to the model and takes into account the cross correlations that may exist between predisposing factors.

Based on the inventory, terrain units are first assigned one of two values corresponding to the presence (1) or absence (0) of movements. A sigmoid curve is then adjusted to the values of the predisposing factors for all terrain units (with and without presence of movements). Coefficients for the predisposing factors (independent variables) are estimated and used, on a second phase, to predict the probability of occurrence of a movement (dependent variable) in each terrain unit. The predisposing factors are of environmental nature and their values are evaluated for each terrain unit. 


\subsubsection{Terrain units}

A terrain unit can be defined as a portion of terrain showing dissimilar properties to the neighboring ones. These can be, for instance, of geological, morphological or geospatial nature.

In this work, the terrain units are the 3D points of the 2014 photogrammetric point cloud decimated to a spatial resolution of $10 \mathrm{~cm}$ resulting in 0.5 million points.

Each point of the 3D point cloud constitutes a work unit in which a probability of occurrence of mass movements will be calculated.

The use of $3 \mathrm{D}$ points as terrain units overcomes some of the disadvantages of using matrix data (rasters) or geomorphological or other geological divisions as point clouds represent the terrain morphology much closer to the reality than the latter.

2.2.2 Rockfall inventory: The mass movement inventory used in the logistic regression analysis presents 90 registered rockfalls that occurred during the period between 1999 and 2014. Each event was defined in the 3D point cloud allowing the definition of the 3D area of the cliff face affected by movements: $12.4 \%$ of the total cliff area.

2.2.3 Predisposing factors to rockfall: Given the very local scale of this work, the predisposing factors selected to characterize the cliff segment were: lithology, presence of faults, presence of water, presence/type of cliff toe protection, height, cliff base height, slope, roughness, aspect and material resistance.

All factors were defined and determined with the best detail level possible. Attribute values for each factor were registered by $3 \mathrm{D}$ edition of the points using a GIS software.

The use of 3D geometric information allows retrieving some of the data automatically, such as height and cliff base height values, roughness and aspect.

It would be expected that slope calculation would automatically be derived but due to the cliff face morphology such procedure is not possible using common GIS operators. The vertical and irregular cliff face of Ribeira d'Ilhas poses some challenges regarding slope calculations referring to a plane resulting in miscalculation.

In order to overcome such difficulties, the $\mathrm{z}$ component of the normal vector was used. For each point and its $n$ neighbours the slope is determined using the expression (1).

$$
\text { slope }=\cos (\mathrm{Nz})
$$

Considering the preferential W-SW direction of high energy weather events and the setting of the Ribeira d'Ilhas cliff face, aspect is a relevant factor. This factor reveals not only the sun incidence in the cliff face (important to the dry/wet cycles that take place in the lower part of the cliff affected by high tides), but also the incidence of the wave action. Its determination for each point of the 3D point cloud is computed from the $x$ and $y$ components of the normal vector (2) (Figure 3 ).

$$
\alpha=\sin ^{-1}\left(\frac{N x}{\sqrt{\left(N x^{2}+N y^{2}\right.}}\right)
$$

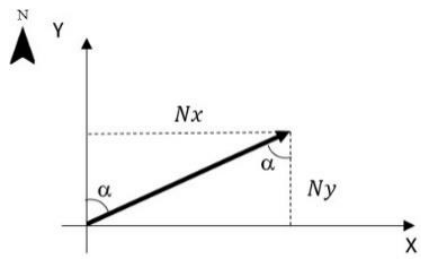

Figure 3. Aspect $(\alpha)$ angle determination by the $x$ and $y$ components of the normal vector to each $3 \mathrm{D}$ point.
A map of the representable predisposing factors is in Figure 4. As lithology is a classification of layers of materials of similar composition (limestones, marls, basalt, etc.), resistance to erosive phenomena can be used to characterize the cliff face: less resistant materials will be worn out more quickly so the areas will recess in the cliff face relatively to more resistant materials that end up being more protruding.

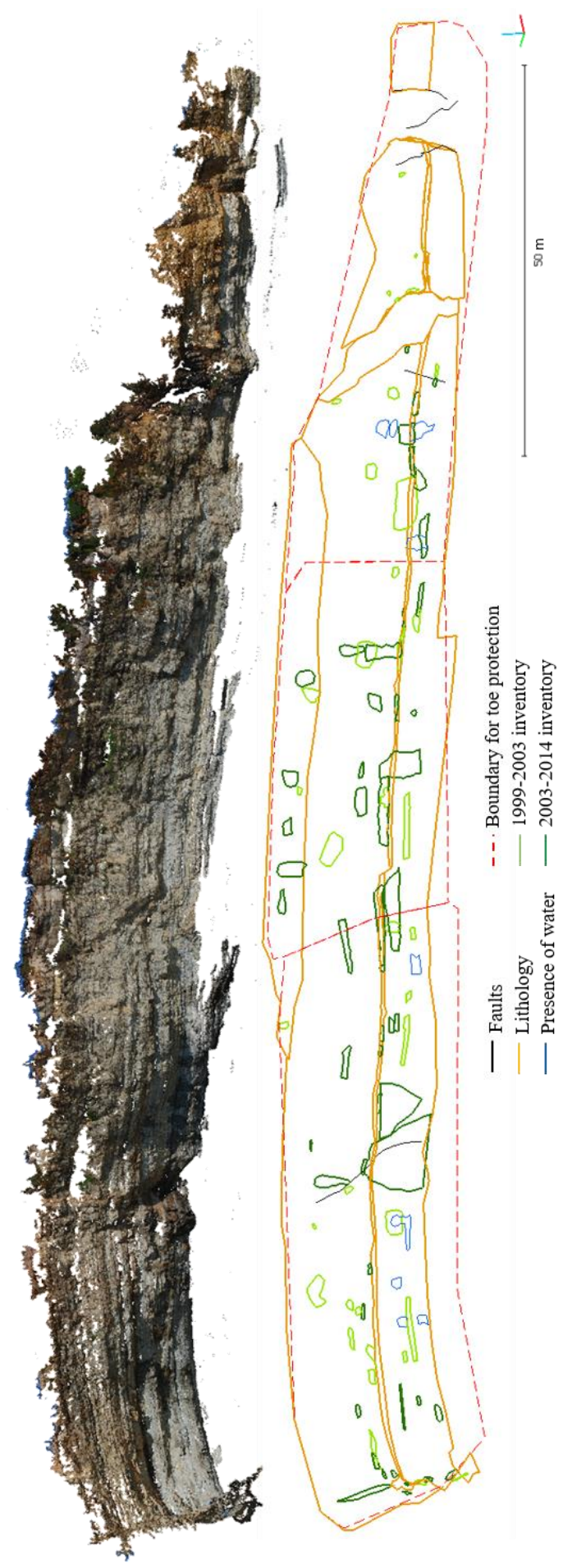

Figure 4. Point cloud and map of predisposing factors and mass movements (Matildes, 2016). 
An indirect quantification of material resistance was achieved in two steps: first, a strong decimation, smoothing and triangulation of the original $3 \mathrm{D}$ point cloud yielded a high frequency filtered reference surface. Then, using the original 3D points, the distance between each point and the reference surface was calculated using the C2M (Cloud2Mesh) algorithm in CloudCompare software (GPL sofware, 2015). The greater the positive distance to the filtered surface, the more resistant the material; the greater the negative distance to the filtered surface, the less resistant the material. Figure 5 shows the results for the estimate throughout the point cloud.

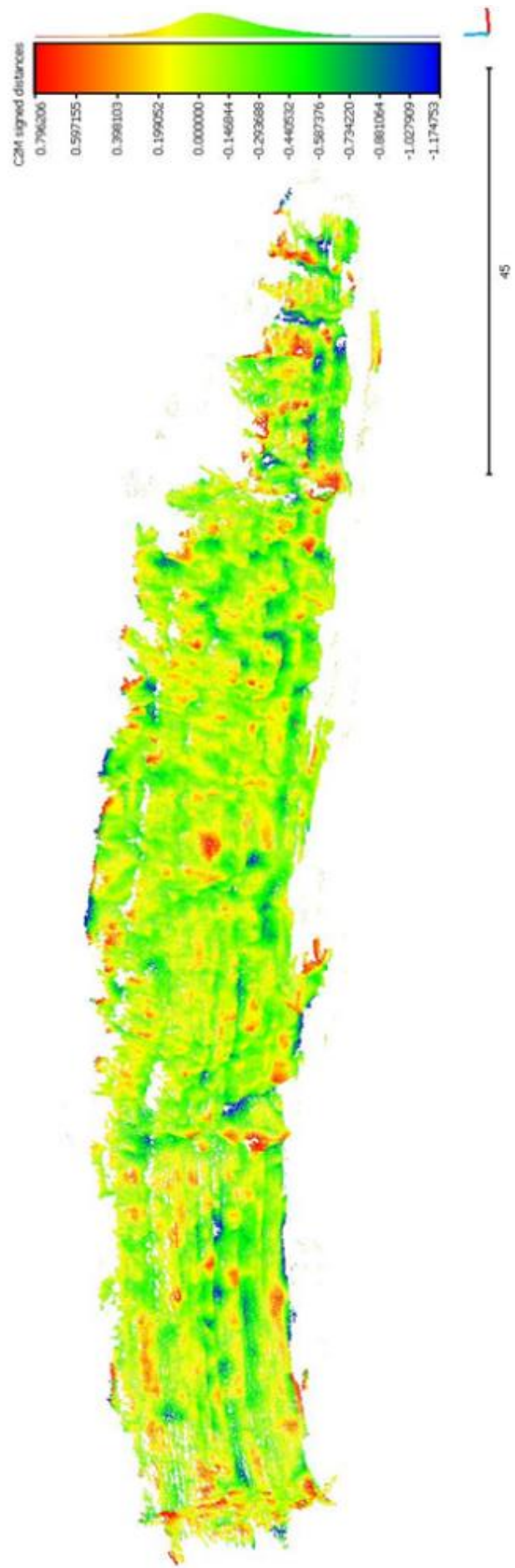

Figure 5. Estimation for the relative resistance of materials. Scale in [m]. (Matildes, 2016).

\subsection{Inputs to the model}

In order to uniform the data and also to not introduce a bias in the weights system, the quantitative factors were divided into classes of similar frequency of terrain units where adequate. Table 1 shows the classes adopted for each factor.

\begin{tabular}{|c|c|c|}
\hline Factor & Classes & $\begin{array}{l}\text { Number of } \\
\text { points }\end{array}$ \\
\hline Lithology & $\begin{array}{l}\text { 1- Sandstone } \\
2 \text { - Basalt } \\
3 \text { - Marl } \\
4 \text { - Marly limestone }\end{array}$ & $\begin{array}{l}56287 \\
10969 \\
201745 \\
137980\end{array}$ \\
\hline Faults & Presence (vs. Absence) & 2267 \\
\hline Water & Presence (vs. Absence) & 4442 \\
\hline $\begin{array}{l}\text { Presence of cliff } \\
\text { toe protection }\end{array}$ & $\begin{array}{l}1 \text { - Debris/Rock blocks } \\
2-\text { Abrasion platform }\end{array}$ & $\begin{array}{l}289228 \\
117753\end{array}$ \\
\hline Height $(\mathrm{m})$ & $\begin{array}{l}1-[0-7.33[ \\
2-[7.33-10.21[ \\
3-[10.21-13.13[ \\
4-[13.13-16.52[ \\
5-[16.52-20.55[ \\
6-[20.55-29[\end{array}$ & $\begin{array}{l}67853 \\
67892 \\
67816 \\
67843 \\
67865 \\
67711 \\
\end{array}$ \\
\hline Slope $\left({ }^{\circ}\right)$ & $\begin{array}{l}1-[0-65[ \\
2-[65-80[ \\
3-[80-90[ \\
4-[90-100[ \\
5-[100-115[ \\
6-[115-180[\end{array}$ & $\begin{array}{l}55925 \\
47484 \\
47945 \\
56122 \\
87123 \\
112382\end{array}$ \\
\hline Roughness & $\begin{array}{l}1-[0-0.008[ \\
2-[0.008-0.021[ \\
3-[0.021-0.031[ \\
4-[0.031-0.047[ \\
5-[0.047-0.063[ \\
6-[0.063-0.094[ \\
7-[0.094-0.367[\end{array}$ & $\begin{array}{l}44705 \\
55573 \\
81543 \\
63677 \\
46405 \\
53327 \\
32883 \\
\end{array}$ \\
\hline Aspect $\left(^{\circ}\right)$ & $\begin{array}{l}1-[-90--10[ \\
2-[-10-10[ \\
3-[10-35[ \\
4-[35-50[ \\
5-[50-60[ \\
6-[60-75[ \\
7-[75-90[\end{array}$ & $\begin{array}{l}33336 \\
34096 \\
74272 \\
68897 \\
54466 \\
77577 \\
64337 \\
\end{array}$ \\
\hline $\begin{array}{l}\text { Material } \\
\text { resistance }\end{array}$ & $\begin{array}{l}1-[-2.16--0.45[ \\
2-[-0.45-0.3[ \\
3-[-0.3--0.17[ \\
4-[-0.17-0[ \\
5-[0-0.15[ \\
6-[0.15-0.5[ \\
7-[0.5-1[ \\
8-[1-2[\end{array}$ & $\begin{array}{l}48122 \\
44142 \\
62754 \\
115475 \\
80339 \\
4808 \\
3892 \\
1175\end{array}$ \\
\hline $\begin{array}{l}\text { Cliff base } \\
\text { height }\end{array}$ & $\begin{array}{l}1-[\min -2.5[ \\
2-[2.5-3[ \\
3-[3-3.5[ \\
4-[3.5-4[ \\
5-[4-4.5[ \\
6-[4.5-5[ \\
7-[5-5.5[ \\
8-[5.5-6[ \\
9-[6-\max [\end{array}$ & \begin{tabular}{l|}
3630 \\
24348 \\
32770 \\
99304 \\
96169 \\
58840 \\
47502 \\
33818 \\
5593 \\
\end{tabular} \\
\hline
\end{tabular}

Table 1. Classification of each predisposing factor and correspondent number of points (terrain units). 


\section{RESULTS}

The susceptibility was modelled using IBM SPSS Statistics which provides the binary logistic regression model and the correspondent model quality tests.

The first statistical analysis of the logistic regression, null model (0), does not consider the independent variables in the model definition and is the base for comparison with the complete model. The null model presents a probability of occurrence of $87.6 \%$.

The following stage computes the complete model (1), that is, considering all independent variables.

The classification table of the model results presents the classification of the observed subjects vs. the classification of the prediction of the adjusted model. The computation of the complete model yielded the results presented in Table 2 .

\begin{tabular}{|c|c|c|c|c|}
\hline & \\
\hline & & \multicolumn{2}{|c|}{$\begin{array}{r}\text { Prediction } \\
\text { Mass movements }\end{array}$} & \multirow{2}{*}{$\begin{array}{c}\text { Correct } \\
\%\end{array}$} \\
\hline & & 0 & 1 & \\
\hline \multirow[t]{2}{*}{$\begin{array}{l}\text { Observed } \\
\text { Movements } \\
\text { - Inventory }\end{array}$} & 0 & $\begin{array}{l}\text { True Negative } \\
\text { (TN): } 355075 \\
(87.31 \%)\end{array}$ & $\begin{array}{l}\text { False } \\
\text { Positive } \\
\text { (FP): } 1120 \\
(0.28 \%)\end{array}$ & 99.7 \\
\hline & 1 & $\begin{array}{l}\text { False } \\
\text { Negative } \\
(\mathrm{FN}): \quad 48538 \\
(11.93 \%)\end{array}$ & $\begin{array}{l}\text { True } \\
\text { Positive } \\
\text { (TP): } 1954 \\
(0.48 \%)\end{array}$ & 3.9 \\
\hline \multicolumn{2}{|l|}{ Global \% } & & & 87.8 \\
\hline
\end{tabular}

Table 2. Classification of logistic regression model results.

The classification table presents four cases: True Negatives (TN), terrain units considered stable and no mass movements were observed; True Positives (TP), terrain units considered unstable and mass movements were observed; False Negatives (FN), terrain units considered stable but mass movements were observed; False Positives (FP), terrain units considered unstable but no mass movements were observed. In an ideal model the sum of TN and TP is $100 \%$. In this case, this result is $87.8 \%$.

Usually, FP and FN represent terrain units where a contradiction between inventory and model prediction is verified. FP may be due to inventorying errors or the characterization of predisposing factors in these terrain units did not allow its classification as unstable. FN may reflect the situation of predisposing factors not accounted for in the model.

The model results can be validated using standard "Receiver Operating Characteristic Curves" (ROC) and the "Area Under the Curve" (AUC) parameter. A model capable of predicting the occurrence or non-occurrence of movements would yield a AUC of 1. According to Guzzetti (2005), acceptable models have an AUC value higher than 0.75 , very satisfactory models higher than 0.8 and excellent models higher than 0.9 .

The value obtained for the AUC was of 0.737 , which is near acceptable (Figure 6).

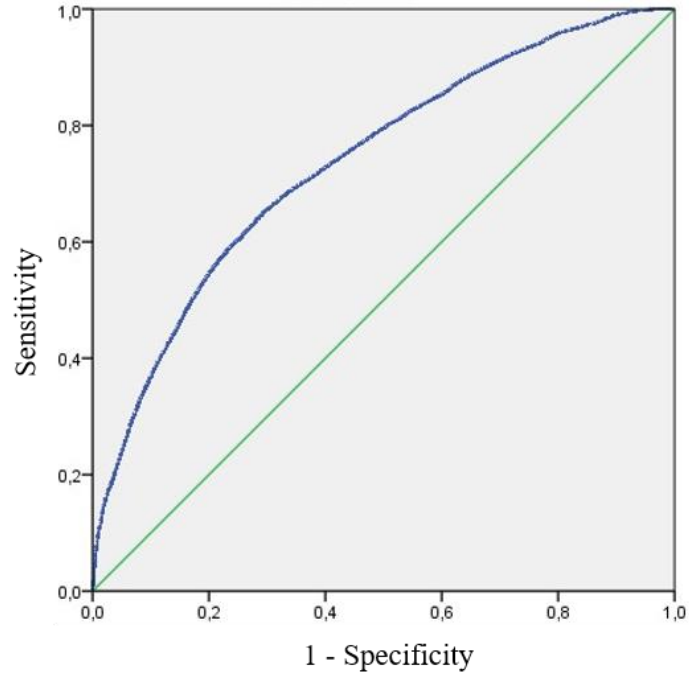

Figure 6. ROC curve for model validation (the green line represents the random model).

The predicted probability is calculated for each terrain unit. The minimum and maximum probability values are 0 and 0.71 respectively. It is possible to represent it spatially, directly in the 3D point cloud (Figure 7).

The logistic regression allows the individual analysis of each predisposing factor and the calculation of the contribution of each of them for the model adjustment. Again, the AUC parameter was used for evaluation.

\begin{tabular}{|c|c|c|}
\hline Predisposing factors & $\overline{\text { AUC }}$ & $\begin{array}{l}\text { Contribution } \\
\text { to AUC }\end{array}$ \\
\hline Cliff base height & 0.62121 & \\
\hline Cliff base height + Lithology & 0.65635 & 0.03514 \\
\hline $\begin{array}{l}\text { Cliff base height }+ \text { Lithology }+ \\
\text { Slope }\end{array}$ & 0.67782 & 0.02147 \\
\hline $\begin{array}{l}\text { Cliff base height }+ \text { Lithology }+ \\
\text { Slope }+ \text { Height }\end{array}$ & 0.72710 & 0.04928 \\
\hline $\begin{array}{l}\text { Cliff base height }+ \text { Lithology }+ \\
\text { Slope }+ \text { Height }+ \text { Material } \\
\text { resistance }\end{array}$ & 0.73176 & 0.00467 \\
\hline $\begin{array}{l}\text { Cliff base height }+ \text { Lithology }+ \\
\text { Slope }+ \text { Height }+ \text { Material } \\
\text { resistance }+ \text { Aspect }\end{array}$ & 0.73235 & 0.00059 \\
\hline $\begin{array}{l}\text { Cliff base height }+ \text { Lithology }+ \\
\text { Slope }+ \text { Height }+ \text { Material } \\
\text { resistance }+ \text { Aspect }+ \text { Roughness }\end{array}$ & 0.73268 & 0.00033 \\
\hline $\begin{array}{l}\text { Cliff base height }+ \text { Lithology }+ \\
\text { Slope }+ \text { Height }+ \text { Material } \\
\text { resistance }+ \text { Aspect }+ \text { Roughness }+ \\
\text { Faults }\end{array}$ & 0.73309 & 0.00040 \\
\hline $\begin{array}{l}\text { Cliff base height }+ \text { Lithology }+ \\
\text { Slope }+ \text { Height }+ \text { Material } \\
\text { resistance }+ \text { Aspect }+ \text { Roughness }+ \\
\text { Faults + Water }\end{array}$ & 0.73309 & 0.00000 \\
\hline
\end{tabular}

Table 3. Contribution of each predisposing factor for the model performance improvement. 

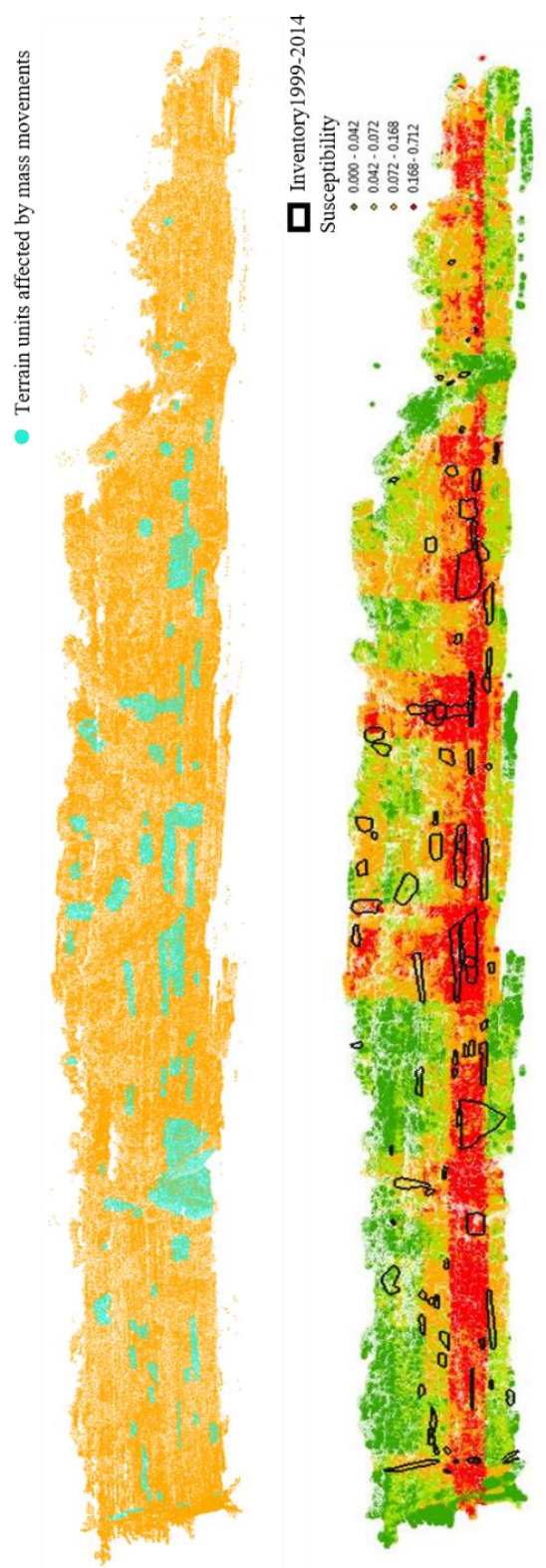

Figure 7. Left: 2014 3D point cloud with terrain units affected by movements highlighted; Right: 3D point cloud classified by mass movement probability of occurrence $(\mathrm{AUC}=0.737)$ with

mass movement inventory superimposed (Matildes, 2016).

\section{CONCLUSIONS}

The occurrences predicting model determined by logistic regression showed to have a prediction capacity of reasonable quality with a value of AUC (ROC) of 0.737 . The individual analysis of each factor allowed the identification of the cliff base height as the most relevant for the model performance, followed by lithology, slope, height and material resistance. For the low performance of the model we identify two causes: - the use of the cliff face topography, especially slope and aspect, to which the mass movements were associated to is a consequence of the movements occurred. Instead mass movements should be associated to the morphology before they occurred;

- most of the predisposing factors considered in this study are referred in the literature for regional scale. For such a local scale study, it is necessary to have higher detail in some factors and to consider new predisposing factors in the work such as fracture analysis, deeper analysis of material resistance, and also a classification that differentiates the generation area and the propagation area of the mass movements.

\section{ACKNOWLEDGEMENTS}

This work was funded by the Portuguese Science and Technology Foundation through the $\mathrm{PhD}$ grant SFRH/BD/72744/2010, and by the project "Creation and implementation of a monitoring system for the littoral of the Administração da Região Hidrográfica do Tejo", funded by QREN program and POVT (POVT-12-0233-FCOES-000034) and by the FCT- project UID/GEO/50019/2019 - Instituto Dom Luiz.

\section{REFERENCES}

Catalão, J., Catita, C., Miranda, J., Dias, J., 2002. Photogrammetric analysis of the coastal erosion in the Algarve (Portugal). Géomorphologie: relief, processus, environment, 2, 119-126.

CloudCompare (version 2.6.2) [GPL software], 2015. http://www.cloudcompare.org/ (20 June 2019).

Collins, B., Stock, G., 2012. Lidar-based rock-fall hazard characterization of cliffs. Proceedings of the 2012 American Society of Civil Engineers GeoCongress, 3021-3030.

Eos Systems, 2013. Photomodeler Scanner (version 2013.1.0.1259 - final, full (64-bit)) [Software]. http://photomodeler.com/products/scanner/default.html (25 June 2019).

Guzzetti, F., 2005. Landslide hazard and risk assessment: concepts, methods and tools for the detection and mapping of landslides, for landslide susceptibility zonation and hazard assessment, and for landslide risk evaluation. ( $\mathrm{PhD}$ thesis). Mathematischnaturwissenschaftliche Rheinischen FriedrichWilhelms Fakultät, Bona University.

Hapke, C.J., 2004. Estimation of regional material yield from coastal landslides based on historical digital terrain modelling. Earth Surface Processes and Landforms, 30, 679-697.

Hoffmeister, D., Tilly, N., Curdt, C., Aasen, H., Ntageretzis, K., Hadler, H., Willershäuser, T., Vött, A., Bareth, G., 2012. Terrestrial laser scanning for coastal geomorphologic research in western Greece. Int. Arch. Photogramm. Remote Sens. Spatial Inf. Sci., XXXIX-B5, 511-516

Horikawa, K., Sunamura, T., 1967. A study on erosion of coastal cliffs by using aerial photographs. Coastal Engineering in Japan, 10, 67-83.

Katz, O., Mushkin, A., 2012. Characteristics of sea-cliff erosion induced by a strong winter storm in the eastern Mediterranean. Quaternary Research, 80, 20-32.

Lague, D., Brodu,N., Leroux, J., 2013. Accurate 3D comparison of complex topography with terrestrial laser scanner: application to the Rangitikei canyon (N-Z). Journal of Photogrammetry and Remote Sensing, 82, 10-26.

Letortu, P., Jaud, M., Grandjean, P., Ammann, J., Costa, S., Maquaire, O., Davidson, R., Le Dantec, N., Delacourt, C., 2018. Examining high-resolution survey methods for monitoring cliff 
erosion at an operational scale. GIScience and Remote Sensing, TaylorFrancis: STM, Behavioural Science and Public Health Titles, 55 (4), 457-476.

DOI: 10.1080/15481603.2017.1408931. hal-01647588

Lim, M., Petley, D., Rosser, N., Allison, R., Long, A., 2005. Combined digital photogrammetry and time-of-flight laser scanning for monitoring cliff evolution. The Photogrammetric Record, 20 (110), 109-129.

Marques, F., 1997. As arribas do litoral do Algarve. Dinâmica, processos e mecanismos. $\mathrm{PhD}$ Thesis (in portuguese) Universidade de Lisboa, 556 pp.

Marques, F., 2006. A simple method for the measurement of cliff retreat from aerial photographs. Zeitschrift für Geomorphologie - Supplementbände, 144, 39-59.

Marques, F., 2008. Magnitude-frequency of sea cliff instabilities. Nat. Hazards Earth Syst. Sci., 8(5), 1161-1171. DOI: https://doi.org/10.5194/nhess-8-1161-2008

Marques, F., 2018. Regional scale sea cliff hazard assessment at Sintra and Cascais counties, western coast of Portugal. Geosciences 8 (3), 80.

DOI:https://doi.org/10.3390/geosciences8030080)

Marques, F., Matildes, R., Redweik, P., 2011. Statistically based sea cliff instability hazard assessment of Burgau-Lagos coastal section (Algarve, Portugal). Journal of Coastal Research, SI 64, 927-931.

Marques, F., Matildes, R., Redweik, P., 2013. Sea cliff instability susceptibility at regional scale: a statistically based assessment in the southern Algarve, Portugal. Nat. Hazards Earth Syst. Sci., 13, 3185-3203.

DOI: https://doi.org/10.5194/nhess-13-3185-2013

Matildes, R., 2009. Detecção fotogramétrica de movimentos em arribas costeiras e gestão do inventário em SIG. MSc Thesis, Universidade de Lisboa. http://hdl.handle.net/10451/3501 (20 June 2019)

Matildes, R., 2016. Técnicas de teledetecção de alta resolução aplicadas à monitorização $3 \mathrm{D}$ de arribas litorais: adequabilidade, modelação da informação e resultados. Instituto Dom Luiz/Fac. Ciências da Universidade de Lisboa. http://repositorio.ul.pt/handle/10451/25380

Oliveira, S., Catalão, J., Ferreira, Ó., Alveirinho Dias, J., 2008. Evaluation of cliff retreat and beach nourishment in southern Portugal using photogrammetric techniques. Journal of Coastal Research, 24 (4c), 184-193.

Queiroz, S., Marques, F., 2019. Sea cliff instability susceptibility considering nearby human occupation and predictive capacity assessment. Engineering Geology, 253, 7593. DOI: https://doi.org/10.1016/j.enggeo.2019.03.009

Redweik, P., Marques, F., Matildes, R., 2008. A strategy for detection and measurement of the cliff retreat of the coast of Algarve (Portugal). Earsel EProceedings Archive, 7(2), 92-104.

Redweik, P., Matildes, R., Marques, F., Santos, L., 2009. Photogrammetric methods for monitoring cliffs with low retreat rate. Journal of Coastal Research, SI 56, 1577- 1581.
Redweik, P., Garzón,V., Pereira, T., 2016. Recovery of Stereo Aerial Coverage from 1934 and 1938 into the Digital Era. The Photogrammetric Record, 31, 9-28

DOI: http://dx.doi.org/10.1111/phor.12137

Rosser, N.J., Petley, D.N., Lim, M., Dunning, S.A., Allison, R.J., 2005. Terrestrial laser scanning for monitoring the process of hard rock coastal cliff erosion. Quarterly Journal of Engineering Geology and Hydrogeology, 38, 363-375.

DOI: 10.1144/1470-9236/05-008.

Salvini, R., Francioni, M., Riccucci, S., Bonciani, F., Callegariv, I., 2013. Photogrammetry and laser scanning for analyzing slope stability and rock fall runout along the Domodossola-Iselle railway, the Italian Alps. Geomorphology $185,110-122$

Sunamura, T., Horikawa, K., 1969. A study on erosion of coastal cliffs by using aerial photographs (Report $n^{\circ} 2$ ). Coastal Engineering in Japan, 12, 99-120.

Zviely, D., Klein, M., 2004, Coastal cliff retreat rates at BeitYannay, Israel, in the 20th century. Earth Surf. Process. Landforms, 2, 175-184. DOI: https://doi.org/10.1002/esp.1019 